\title{
PENGEMBANGAN EVALUASI PEMBELAJARAN BAHASA INDONESIA BERBASIS TAKSONOMI STRUCTURE OF OBSERVED LEARNING OUTCOME
}

\author{
Subyantoro \\ FBS Universitas Negeri Semarang \\ email: b3ntoro_peneliti@yahoo.co.id
}

\begin{abstract}
Abstrak
Penelitian bertujuan mendeskripsikan karakteristik, prinsip pengembangan, dan menguji keefektifan perangkat evaluasi berdasarkan taksonomi Structure of Observed Learning Outcome (SOLO) pada mata pelajaran Bahasa Indonesia. Penelitian menggunakan desain penelitian dan pengembangan. Penelitian ini sampai pada tahap ke tujuh, yaitu operational product revision, revisi setelah mendapatkan masukan dari tes lapangan. Hasil penelitian sebagai berikut. Pertama, karakteristik perangkat evaluasi meliputi jenis soal, waktu yang digunakan, penugasan, kemampuan berpikir kritis, dan kemampuan memecahkan masalah. Kedua, prinsip pengembangan perangkat evaluasi meliputi jenis soal yang cocok, penugasan, kemampuan berpikir kritis, dan kemampuan memecahkan masalah. Ketiga, perangkat evaluasi berisi konsep materi, pembuatan kisi-kisi evaluasi, kartu soal, paket soal dan petunjuk pengerjaan, kunci jawaban dilengkapi rubrik penilaian dan penskoran. Keempat, keefektifan perangkat evaluasi diketahui dari validitas, reliabilitas, indeks kesukaran, dan daya beda soal.
\end{abstract}

Kata kunci: perangkat evaluasi, taksonomi SOLO, berpikir kritis

\section{DEVELOPING EVALUATION OF INDONESIAN LANGUAGE LEARNING BASED ON THE TAXONOMY OF THE STRUCTURE OF OBSERVED LEARNING OUTCOME}

\begin{abstract}
This study aims to describe characteristics and principles of the development of evaluation kits based on the taxonomy of the Structure of Observed Learning Outcome (SOLO) in the Bahasa Indonesia subject and to test the effectiveness. It employed a research and development design. It was conducted up to the seventh stage, namely operational product revision, a revision after obtaining feedback from field testing. The results of the study are as follows. First, the characteristics of the evaluation kits include item types, time allocation, tasks, critical thinking skills, and problem solving skills. Second, the principles of the development of evaluation kits include appropriate item types, tasks, critical thinking skills, and problem solving skills. Third, the evaluation kits consist of conceptual materials, evaluation grids, item cards, test packages and instructions, and answer keys accompanied by assessment and scoring rubrics. Fourth, the effectiveness of the evaluation kits is indicated by the test validity and reliability and the item difficulty index and discrimination index.
\end{abstract}

Keywords: evaluation kits, SOLO taxonomy, critical thinking

\section{PENDAHULUAN}

Model evaluasi hasil belajar peserta didikyang dikembangkan guru khususnya untuk mengukur pencapaian kompetensi berbahasa dan bersastra pada umumnya masih belum memberikan ruang berpikir 
tingkat tinggi kepada peserta didik. Masih banyaknya guru bahasa Indonesia kurang kompeten dalam merancang program dan menyusun perangkat evaluasi pembelajaran yang sesuai dengan indikator yang dituntut berdasarkan kompetensi dasar dapat diketahui dalam forum MGMP dan ketika para guru dituntut menyusun kisi-kisi soal dan menerjemahkan kisikisi ke dalam bentuk soal. Pedoman dan buku-buku evaluasi yang digunakan para guru umumnya hanya berupa kumpulan soal-soal pilihan ganda demi sukses UN, sukses masuk perguruan tinggi dengan informasi materi yang terbatas dan taktik pengerjaan yang serba instan semakin memperpanjang permasalahan dalam pembelajaran bahasa dan sastra Indonesia khususnya dalam hal pengembangan perangkat evaluasi mata pelajaran bahasa dan sastra Indonesia.

Menurut Djiwandono (2008:2) evaluasi merupakan bagian yang tidak terpisahkan dari proses pembelajaran secara keseluruhan dalam pembelajaran bahasa. Pembelajaran bahasa diselenggarakan untuk mencapai tujuan pembelajaran yang telah diidentifikasi berdasarkan kebutuhan yang ada. Tujuan pembelajaran tersebut dapat tercapai melalui proses pembelajaran dengan memanfaatkan bahan ajar yang sesuai. Upaya untuk mengetahui tingkat ketercapaian tujuan pembelajaran adalah melalui evaluasi pembelajaran. Itulah hakikatnya kedudukan evaluasi pembelajaran dalam desain penyelenggaraan pembelajaran sebagai akhir dari rangkaian tiga komponen pokok penyelenggaraan pembelajaran, yaitu tujuan pembelajaran, kegiatan pembelajaran, dan evaluasi pembelajaran.

Evaluasi pembelajaran perlu dilakukan secara tepat dan melibatkan peserta didik, alasannya ialah, (a) para peserta didik mengembangkan perasaan aman (psikologis) ketika mereka berpartisipasi dalam evaluasi. Artinya dengan evaluasi pembelajaran, peserta didik tidak merasa terbebani melainkan senang karena ada balikan (feedback), (b) evaluasi dapat menjadikan belajar lebih menyenangkan. Peserta didik ada kecenderungan termotivasi dalam belajar manakala mereka memiliki pengalaman berhasil mencapai nilai atau grade standar yang telah ditentukan dalam evaluasi hasil belajar, dan (c) evaluasi dapat menjadikan teknik belajar mengajar lebih berhasil (Hamalik 2008:210).

Tujuan penelitian ini (1) mengidentifikasi karakteristik perangkat evaluasi berdasarkan taksonomi SOLO pada mata pelajaran Bahasa Indonesia; (2) Merumuskan prinsip-prinsip pengembangan perangkat evaluasi berdasarkan taksonomi SOLO pada mata pelajaran Bahasa Indonesia; (3) menyusun prototipe perangkat evaluasi berdasarkan taksonomi SOLO pada mata pelajaran Bahasa Indonesia, dan (4) menguji keefektifan perangkat evaluasi berdasarkan taksonomi SOLO pada mata pelajaran Bahasa Indonesia.

Bloom (1979) untuk keperluan pengukuran hasil belajar ranah kognitif membedakan ke dalam enam tingkatan dan berlaku umum untuk semua kompetensi hasil belajar. Di samping itu pula, terdapat jenis taksonomi yang lain, yakni taksonomi yang dikembangkan oleh Biggs dan Collis (1982:15) yang kemudian dikenal dengan taksonomi SOLO. Taksonomi itu mengklasifikasikan tingkat kemampuan peserta didik pada lima level berbeda dan bersifat hierarkis, yaitu prastruktural (prestructural), unistruktural (unistructural), multistruktural (multystructural), relasional (relational), abstrak diperluas (extended abstract) (Kenny 2002:25). Kla-sifikasi ini didasarkan pada keragaman berpikir peserta didik pada saat merespon masalah yang disajikan.

Taksonomi SOLO dipandang menarik untuk diaplikasikan dalam menilai hasil belajar di sekolah, khususnya sebagai alternatif lain dalam evaluasi hasil bela- 
jar karena di samping bersifat hierarkis juga menuntut kemampuan peserta didik memberikan beberapa alternatif jawaban atau penyelesaian serta mampu mengaitkan beberapa jawaban atau penyelesaian tersebut. Taksonomi ini memberikan peluang pada peserta didik untuk selalu berpikir alternatif (kemampuan pada level multistruktural), membandingkan antara suatu alternatif dengan alternatif yang lain (kemampuan pada level relasional), serta memberikan peluang pada peserta didik untuk mampu memberikan suatu yang baru dan berbeda dari biasanya (kemampuan pada level abstrak diperluas atau extended abstract). Artinya taksonomi ini di samping mangakomodasi tujuan langsung juga dipandang mampu mengakomodasi tujuan tidak langsung pembelajaran sastra Indonesia dan memberi peluang kepada peserta didik untuk berpikir pada level kognitif tingkat tinggi. Untuk menjawab permasalahan yang pada umumnya mengundang banyak jawaban atau penafsiran ganda, jenis soal pilihan ganda yang selama ini ada akan tepat kiranya jika peserta didik diberi kesempatan pula untuk memberi respons (jawaban) tambahan. Respons inilah yang dapat dijadikan bahan amatan bagi guru tentang seberapa tinggi tingkat berpikir peserta didik. Berada di level apakah tingkat berpikirnya. Inilah yang terakomodasi dalam taksonomi SOLO. Oleh karena itulah, layak kiranya taksonomi ini diterapkan dalam pengembangan alat evaluasi uji kompetensi membaca dan menulis.

Diketahui bersama bahwa kegiatan penilaian atau evaluasi bukanlah merupakan hal baru bagi guru atau praktisi pendidikan karena merancang dan melaksanakan penilaian merupakan serangkaian tugas pokok dan fungsi guru. Namun, kenyataan menunjukkan bahwa merencanakan dan melaksanakan penilaian masih merupakan persoalan serius. Berdasarkan hasil penelitian ten- tang kesiapan guru dalam melaksakan Kurikulum Berbasis Kompetensi (KBK) dan disempurnakan dalam Kurikulum Tingkat Satuan Pendidikan (KTSP), antara lain ditemukan bahwa kemampuan guru dalam menyiapkan dan melakukan penilaian masih kurang dan bahkan masih banyak guru yang belum memiliki pemahaman yang memadai tentang sistem penilaian yang sesuai dengan penerapan kurikulum yang berlaku. Hasil supervisi dan evaluasi implementasi keterlaksanaan KTSP Tahun 2009 ditemukan masih banyaknya guru yang belum sepenuhnya memahami pengertian dan prinsip penilaian serta kaitannya dengan nilai mata pelajaran, mekanisme dan prosedur penilaian, penyiapan perangkat, serta implementasinya

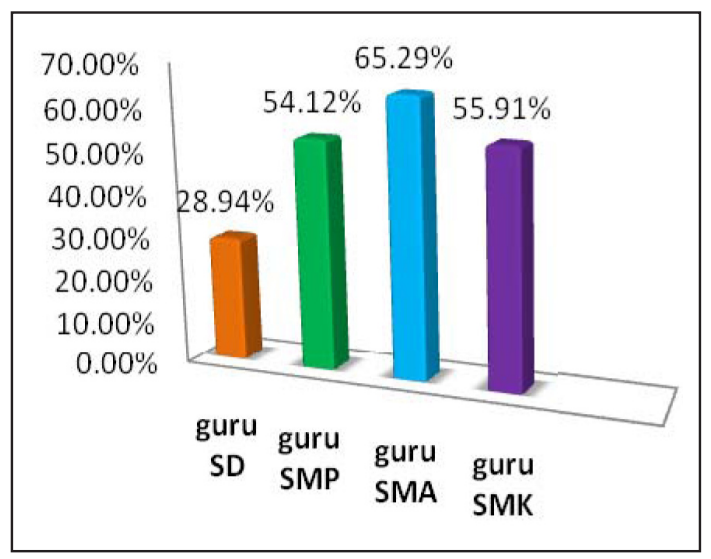

Diagram 1. Data Kelayakan Profesi Guru di Indonesia

(Surya Dharma, 2009 Balitbang Depdiknas)

Rendahnya profesionalitas guru di Indonesia dilihat dari kelayakan guru mengajar termasuk di dalamnya penyiapan perangkat evaluasi menurut Dharma (2009:10), input guru di Indonesia sangat rendah.

Kayanni et al. (2010:12) mengungkapkan bahwa peningkatan kualitas pendidikan memerlukan perbaikan proses pembelajaran di sekolah dengan menerapkan cara kerja sistematis yang salah satunya dapat dimulai dari pembenahan 
sistem asesmen (penilaian). Pendapat ini mengandung makna bahwa untuk memperbaiki sistem pembelajaran di sekolah diperlukan sejumlah informasi dari hasil kegiatan asesmen yang dilakukan secara sistematis dan profesional oleh guru, sekolah, maupun institusi pendidikan.

Berdasarkan sejumlah pendapat tersebut, kualitas pendidikan tidak dapat dilepaskan dari prosedur evaluasi pendidikan. Untuk memperbaiki kualitas pendidikan haruslah diciptakan sistem evaluasi yang lebih baik. Sistem evalusi (kegiatan pengukuran/pengujian, penilaian, hingga kegiatan evaluasi) ini selain prosedurnya yang harus sistematis, pelaksanaannya pun harus memiliki akuntabilitas yang tinggi, serta hasilnya diharapkan mendapatkan pengakuan dari stakeholders pendidikan. Namun, harus diakui bahwa sistem evaluasi yang diterapkan selama ini masih mengalami berbagai masalah, terutama di tingkat sekolah. Bukan saja karena hasil-hasilnya, tetapi mekanisme dan prosedur pelaksanaanya pun masih memiliki berbagai kelemahan. Akibatnya, sistem evaluasi yang diharapkan memberikan input terhadap perbaikan kualitas pendidikan melalui perbaikan sistem pembelajaran di sekolah dirasakan hasilnya belum optimal.

Dahmani (2012:9) menemukan beberapa hal yang membuat sistem evaluasi hasil belajar yang dilakukan di sekolah belum mendukung peningkatan kualitas pendidikan, antara lain: (1) kulitas tes buatan guru masih kurang memadai; (2) jaringan pengujian di daerah belum dimanfaatkan dengan baik; (3) pelaporan hasil penyelenggaraan ujian oleh guru kepada kepala sekolah belum terlaksana secara rutin; dan (4) hasil-hasil ujian belum dimanfaatkan secara optimal untuk perbaikan proses pembelajaran di kelas.

\section{METODE}

Pendekatan penelitian yang digunakan dalam penelitian ini adalah pene- litian dan pengembangan atau research and development $(R \mathcal{E} D)$. Tahapan research and development menurut Borg dan Gall (1983:775-776) adalah (1) research and information collecting, pengumpulan informasi dan penelitian awal; (2) planing, perencanaan; (3) develop preliminary form of product, pengembangan format atau model; (4) preliminary field testing, persiapan uji coba tes di lapangan, (5) main product revision, revisi terhadap produk yang akan diujicobakan di lapangan; (6) main field testing, tes di lapangan; (7) operational product revisions, revisi setelah mendapatkan masukan dari tes lapangan; (8) operational field testing, pelaksanaan tes uji coba model atau tes pembelajaran; (9) final product revision, revisi terakhir produk; (10) dominition and implementation.

Sesuai dengan kebutuhan penelitian ini dan kondisi penelitian yang sebenarnya, tahapan penelitian yang dilaksanakan sampai pada tahap ketujuh dengan pertimbangan (1) langkah 8, 9, dan 10 dari R\&D Borg dan Gall merupakan penelitian lanjutan yang berujung pada penerapan dan desiminasi nasional yang membutuhkan waktu yang lama, biaya yang besar, serta menghabiskan banyak tenaga; (2) tahap lanjutan ini serupa dengan tahap evaluasi sumatif yang dijelaskan bahwa tahap ini bukanlah bagian dari proses desain karena biasanya tidak melibatkan perancangan melainkan melibatkan evaluator independen.

Subjek penelitian ini adalah pengembangan perangkat evaluasi dengan taksonomi SOLO. Sumber data penetilian ini terdiri atas peserta didik, guru, dan ahli. Data yang dikumpulkan untuk keperluan penelitian ini ada tiga macam, yaitu. Pertama, data kebutuhan pengembangan perangkat evaluasi dengan taksonomi SOLO. Kedua, data penilaian ahli tentang draf perangkat evaluasi dengan taksonomi SOLO. Ketiga, data uji coba terbatas draf perangkat evaluasi dengan taksonomi SOLO. 
Pada pengambilan data tentang kebutuhan perangkat evaluasi data penelitiannya adalah peserta didik dan guru. Data kedua bersumber dari ahli bidang menulis serta ahli bidang evaluasi pembelajaran. Para ahli tersebut merupakan sumber data untuk memperoleh masukan perbaikan draf perangkat evaluasi dengan taksonomi SOLO. Data ketiga diperoleh dari sumber peserta didik. Peserta didik tersebut merupakan sumber data untuk memperoleh gambaran validitas, reliabilitas, daya beda, dan tingkat kesukaran soal yang berada pada perangkat evaluasi dengan taksonomi SOLO yang telah dibuat.

\section{HASIL DAN PEMBAHASAN Karakteristik Perangkat Evaluasi Ber- dasarkan Taksonomi SOLO}

Karakteristik perangkat evaluasi berdasarkan taksonomi SOLO kompetensi menulis dan membaca yang sesuai dengan kebutuhan peserta didik berdasarkan hasil angket dari 40 responden meliputi hal sebagai berikut. Jenis soal yang digunakan adalah soal pilihan ganda, esai, menjodohkan, dan penugasan dengan cara penyelesaian berbeda. Waktu yang digunakan dalam penyelesaian soal disesuaikan dengan jumlah soal dan jenis soal. Hal ini berarti peserta didik memberi masukan dalam pengembangan perangkat evaluasi berdasarkan taksonomi SOLO kompetensi menulis dan membaca. Karakteristik perangkat evaluasi berdasarkan taksonomi SOLO kompetensi menulis dan membaca yang sesuai dengan kebutuhan guru berdasarkan hasil angket dari 4 responden, yang meliputi: (1) soal pilihan ganda meliputi: karakteristik jawaban pilihan ganda, jumlah kata pada tiap kalimat pertanyaan, jumlah kalimat pada soal, jumlah paragraf pada soal, jumlah pernyataan pada soal, waktu yang ditentukan, jumlah soal yang harus dikerjakan, keharusan ada soal dengan tingkat unistruktural, kekeharusan ada soal dengan tingkat multistruktural, ke- harusan ada soal dengan tingkat relasional, keharusan ada soal dengan tingkat abstrak; (2) soal esai meliputi: karakteristik jawaban soal esai, jumlah kata pada tiap kalimat pertanyaan, jumlah kalimat pada soal, jumlah paragraf pada soal, jumlah pernyataan pada soal, waktu yang ditentukan, jumlah soal yang harus dikerjakan, keharusan ada soal dengan tingkat unistruktural, keharusan ada soal dengan tingkat multistruktural, keharusan ada soal dengan tingkat relasional, keharusan ada soal dengan tingkat abstrak; (3) soal menjodohkan meliputi: karakeristik jawaban soal menjodohkan, jumlah kata pada tiap kalimat pertanyaan, jumlah kalimat pada soal, jumlah paragraf pada soal, jumlah pernyataan pada soal, waktu yang ditentukan, jumlah soal yang harus dikerjakan, keharusan ada soal dengan tingkat unistruktural, keharusan ada soal dengan tingkat multistruktural, keharusan ada soal dengan tingkat relasional, keharusan ada soal dengan tingkat abstrak; (4) soal penugasan meliputi: karakteristik karakter jawaban penugasan, jumlah kata pada tiap kalimat pertanyaan, jumlah kalimat pada soal, jumlah paragraf pada soal, jumlah pernyataan pada soal, waktu yang ditentukan, jumlah soal yang harus dikerjakan, keharusan ada soal dengan tingkat unistruktural, keharusan ada soal dengan tingkat multistruktural, keharusan ada soal dengan tingkat relasional, keharusan ada soal dengan tingkat abstrak; (5) kemampuan berpikir kritis meliputi: karakteristik kemampuan meringkas, kemampuan menyimpulkan, kemampuan berpendapat, kemampuan mengelompokkan, dan kemampuan menciptakan; dan (6) kemampuan memecahkan masalah meliputi: karakteristik kemampuan memahami kata, kemampuan memilih masalah sendiri, kemampuan memecahkan masalah berdasarkan data dan masalah, dan kemampuan menggunakan analogi. Hal ini berarti guru memberi masukan dalam pengembangan perangkat evaluasi ber- 
dasarkan taksonomi SOLO kompetensi menulis dan membaca.

\section{Prinsip Pengembangan Perangkat Evalua- si Berdasarkan Taksonomi SOLO}

Prinsip pengembangan perangkat evaluasi berdasarkan taksonomi SOLO untuk kompetensi menulis dan membaca kelas IV dan V SD, VII dan VIII SMP, X dan XI SMA meliputi: (1) jenis soal yang cocok dikembangkan meliputi soal pilihan ganda, soal esai, soal menjodohkan, dan soal penugasan; (2) soal pilihan ganda dikembangkan dengan memperhatikan karakter jawaban pilihan ganda, jumlah kata pada tiap kalimat pertanyaan, jumlah kalimat pada soal, jumlah paragraf pada soal, jumlah pernyataan pada soal, waktu yang ditentukan, jumlah soal yang harus dikerjakan, keharusan ada soal dengan tingkat unistruktural, keharusan ada soal dengan tingkat multistruktural, keharusan ada soal dengan tingkat relasional, keharusan ada soal dengan tingkat abstrak; (3) soal esai dikembangkan dengan memperhatikan karakter jawaban soal esai, jumlah kata pada tiap kalimat pertanyaan, jumlah kalimat pada soal, jumlah paragraf pada soal, jumlah pernyataan pada soal, waktu yang ditentukan, jumlah soal yang harus dikerjakan, keharusan ada soal dengan tingkat unistruktural, keharusan ada soal dengan tingkat multistruktural, keharusan ada soal dengan tingkat relasional, keharusan ada soal dengan tingkat abstrak; (4) soal menjodohkan dikembangkan dengan memperhatikan karakter jawaban soal menjodohkan, jumlah kata pada tiap kalimat pertanyaan, jumlah kalimat pada soal, jumlah paragraf pada soal, jumlah pernyataan pada soal, waktu yang ditentukan, jumlah soal yang harus dikerjakan, keharusan ada soal dengan tingkat unistruktural, keharusan ada soal dengan tingkat multistruktural, keharusan ada soal dengan tingkat relasional, keharusan ada soal dengan tingkat abstrak; (5) soal penugasan dikembangkan dengan memperhatikan karakter jawaban penugasan, jumlah kata pada tiap kalimat pertanyaan, jumlah kalimat pada soal, jumlah paragraf pada soal, jumlah pernyataan pada soal, waktu yang ditentukan, jumlah soal yang harus dikerjakan, keharusan ada soal dengan tingkat unistruktural, keharusan ada soal dengan tingkat multistruktural, keharusan ada soal dengan tingkat relasional, keharusan ada soal dengan tingkat abstrak; (6) jenis soal untuk kemampuan berpikir kritis dikembangkan dengan memperhatikan kemampuan meringkas, kemampuan menyimpulkan, kemampuan berpendapat, kemampuan mengelompokkan, dan kemampuan menciptakan; dan (7) jenis soal untuk kemampuan memecahkan masalah dikembangkan dengan memperhatikan kemampuan memahami kata, kemampuan memilih masalah sendiri, kemampuan memecahkan masalah berdasarkan data dan masalah, dan kemampuan menggunakan analogi.

\section{Perangkat Evaluasi Berdasarkan Tak- sonomi SOLO dan Pengujiannya}

Produk pengembangan dalam penelitian ini berupa perangkat evaluasi berdasarkan taksonomi SOLO kompetensi menulis dan membaca. Isi perangkat evaluasi berdasarkan taksonomi SOLO kompetensi menulis dan membaca berupa konseptual materi, kisi-kisi evaluasi, kartu soal, paket soal lengkap dengan petunjuk pengerjaan, kunci jawaban dan rubrik penilaian dan peskoran.

Perangkat evaluasi berdasarkan taksonomi SOLO kompetensi menulis dan membaca dilihat dari validitas, reabilitas, indeks tingkat kesukaran, dan daya pembeda soal. Dalam paket soal membaca pantun secara berbalasan, ada 20 butir soal yang diujikan, 18 butir soal dinyatakan valid, sedangkan dua butir soal tidak valid, meliputi butir soal nomor 9 dan 10 . Oleh karena itu, hanyalah 18 butir soal yang dapat digunakan dalam evaluasi 
pembelajaran membaca pantun secara berbalasan. Dalam paket soal menulis karangan, ada 18 butir soal yang diujikan. 16 butir soal dinyatakan valid sedangkan 2 butir soal tidak valid, yaitu butir soal nomor 14 dan 15. Oleh karena itu, hanya 16 soal yang dapat digunakan dalam evaluasi pembelajaran menulis karangan. Dalam paket soal menulis surat undangan, ada 19 butur soal yang diujikan. 17 butir soal dinyatakan valid sedangkan 2 butir soal tidak valid, yaitu nomor 10 dan 16 . Oleh karena itu, hanya 17 soal yang dapat digunakan dalam evaluasi pembelajaran menulis surat undangan. Dalam paket soal menulis dialog sederhana, ada 14 butir soal yang diujikan. 12 butir soal dinyatakan valid sedangkan 2 butir soal tidak valid, yaitu nomor 4 dan 9. Oleh karena itu, hanya 12 soal yang dapat digunakan dalam evaluasi pembelajaran menulis surat undangan. Pada paket kompetensi dasar menulis pengalaman dalam buku harian, disajikan sepuluh soal pilihan ganda dan satu soal berbentuk uraian. Soal pada kompetensi ini diujicobakan kepada 14 peserta didik SMP dengan skor capaian 96 dengan rincian dari sepuluh soal yang diujikan delapan soal dinyatakan valid dan dua soal dinyatakan tidak valid. Soal yang dinyakan valid yaitu soal nomor 1, 2, 3, 4, 6, 7, dan 9. Soal yang dinyatakan tidak valid adalah soal nomor 5 dan 10. Ketidakvalidan soal tersebut dikarenakan soal pada nomor 5 dan 10 dianggap sukar karena hanya 8 peserta didik yang menjawab benar dari 14 peserta didik.

Dalam paket soal membaca pantun berbalasan, ada 20 butir soal yang diujikan. Dari 15 soal pilihan ganda dan rumpang yang dikerjakan, mendapat angka 0,676 atau masuk dalam kriteria reliabel. Dari tiga soal esai yang dikerjakan, mendapat angka 0,45067583 atau masuk dalam kriteria reliabel. Dalam paket soal menulis karangan, ada 18 butur soal yang diujikan. Dari 15 soal pilihan ganda dan menjodohkan yang dikerjakan, mendapat angka 0,70396 atau masuk dalam kriteria reliabel. Dari tiga soal esai yang dikerjakan, mendapat angka 0,357 atau masuk dalam kriteria reliabel. Dalam paket soal menulis surat undangan, ada 19 butir soal yang diujikan. Dari 16 soal pilihan ganda dan menjodohkan yang dikerjakan, mendapat angka 0,7519 atau masuk dalam kriteria reliabel. Dari tiga soal esai yang dikerjakan, mendapat angka 0,61134454 atau masuk dalam kriteria reliabel. Dalam paket soal menulis dialog sederhana, ada 14 butur soal yang diujikan. Dari 11 soal pilihan ganda dan menjodohkan yang dikerjakan, mendapat angka 0,630 atau masuk dalam kriteria reliabel. Dari tiga soal esai yang dikerjakan, mendapat angka 0,648562 atau masuk dalam kriteria reliabel. Pada penelitian ini, setelah instrumen tes hasil belajar sebanyak 10 butir kompetensi dasar menulis pengalaman dalam buku harian diujicobakan, diperoleh reliabilitas 1, 786 .

Dalam paket soal membaca pantun berbalasan, ada 20 butir soal yang diujikan. Dengan kriteria indeks kesukaran, dari 20 soal itu diperoleh 14 soal dengan kategori mudah, 5 soal dengan kategori sedang dan 1 soal dengan kategori sukar. Dalam paket soal menulis karangan, ada 18 butur soal yang diujikan. Dengan kriteria indeks kesukaran, dari 18 soal itu diperoleh 9 soal dengan kategori mudah, 6 soal dengan kategori sedang dan 3 soal dengan kategori sukar. Dalam paket soal menulis surat undangan, ada 19 butir soal yang diujikan. Dengan kriteria indeks kesukaran, dari 19 soal itu diperoleh 5 soal dengan kategori mudah, 10 soal dengan kategori sedang dan 4 soal dengan kategori sukar. Dalam paket soal menulis dialog sederhana, ada 14 butur soal yang diujikan. Dengan kriteria indeks kesukaran, dari 14 soal itu diperoleh 3 soal dengan kategori mudah, 8 soal dengan kategori sedang dan 3 soal dengan kategori sukar. Pada penelitian ini, setelah instrumen tes 
hasil belajar sebanyak 10 butir kompetensi dasar menulis pengalaman dalam buku harian diujicobakan, berdasarkan kriteria indeks kesukaran soal tersebut diperoleh 4 soal dengan kategori mudah, dan 6 soal dengan kategori sedang.

Dalam paket soal membaca pantun berbalasan, ada 20 butir soal yang diujikan. Dengan kriteria daya pembeda soal diperoleh 0 butir soal dengan kriteria baik sekali, 2 butir soal dengan kriteria baik, 15 butir soal dengan kriteria cukup, dan 3 butir soal dengan kriteria jelek. Dalam paket soal menulis karangan, ada 18 butir soal yang diujikan. Dengan kriteria daya pembeda soal diperoleh 3 butir soal dengan kriteria baik sekali, 3 butir soal dengan kriteria baik, 8 butir soal dengan kriteria cukup, dan 4 butir soal dengan kriteria jelek. Dalam paket soal menulis surat undangan, ada 19 butur soal yang diujikan. Dengan kriteria daya pembeda soal diperoleh 1 butir soal dengan kriteria baik sekali, 4 butir soal dengan kriteria baik, 8 butir soal dengan kriteria cukup, dan 6 butir soal dengan kriteria jelek. Dalam paket soal menulis dialog sederhana, ada 14 butur soal yang diujikan. Dengan kriteria daya pembeda soal diperoleh 3 butir soal dengan kriteria baik sekali, tidak ada butir soal dengan kriteria baik, 7 butir soal dengan kriteria cukup, dan 4 butir soal dengan kriteria jelek. Pada penelitian ini, setelah instrumen tes hasil belajar sebanyak 10 butir kompetensi dasar menulis pengalaman dalam buku harian diujicobakan, berdasarkan kriteria daya pembeda soal diperoleh 3 butir soal dengan kriteria baik sekali, 2 butir soal dengan kriteria baik, 3 butir soal dengan kriteria cukup dan 1 butir soal dengan kriteria jelek.

Tingkat keberterimaan guru terhadap perangkat evaluasi berdasarkan taksonomi SOLO dilakukan dengan wawancara dan pengisian rubrik. Dari hasil wawancara sebagaimana terlampir dalam transkrip wawancara dapat disimpulkan bahwa guru-guru bahasa Indonesia menyambut dengan baik penerapan taksonomi SOLO dalam pengembangan perangkat evaluasi.

Hasil rubrik keberterimaan peserta didik terhadap perangkat evaluasi dengan taksonomi SOLO yang diiisi oleh 32 peserta didik diperoleh hasil sebagai berikut.

1) Berdasarkan rubrik yang menanyakan perihal perasaan peserta didik (senang, tidak senang, atau biasabiasa saja) selama melakukan kegiatan evaluasi hasil belajar, $81 \%$ peserta didik atau sebanyak 26 orang menjawab senang, sedangkan sisanya $10 \%$ peserta didik yakni 7 peserta didik menjawab biasa-biasa saja.

2) Ketika diajukan pertanyaan yang menyangkut kecocokan (cocok sekali, tidak cocok, atau biasa-biasa saja) terhadap model evaluasi dengan taksonomi SOLO (menyertakan respon jawaban) 27 peserta didik atau $84 \%$ peserta didik menjawab cocok sekali, dan 2 orang menjawab biasa-biasa saja.

Dari hasil wawancara dengan perwakilan dua orang peserta didik diperoleh hasil bahwa penialain hasil belajar dengan cara memberi kesempatan kepada peserta didik untuk memberikan alasan atas pilihan jawaban jika perangkat tes berupa soal pilihan ganda menurut meraka sangat tepat, karena peserta didik diberi kesempatan untuk mengutarakan pendaparnya. Di samping itu mereka juga merasa memperoleh keadilan atas pelaksanaan ujian/tes yang mereka lakukan. Peserta didik juga akan semakin rajin membaca.

Dengan demikian, dapat disimpulkan bahwa peserta didik menerima, sangat membutuhkan, dan sangat cocok terhadap penerapan taksonomi SOLO dalam kegiatan evaluasi hasil belajar. 


\section{Pembahasan Hasil Penelitian}

Untuk mengakomodasi berpikir tingkat tinggi yakni berpikir kritis yang meliputi kemampuan mengidentifikasi, menyimpulkan, menganalisis, mengaplikasi, dan kemampuan merefleksi jenis instrumen penilaian yang tepat menurut guru adalah penugasan dan esai/uraian. Demikian pula untuk kemampuan memecahkan masalah seperti membuat hipotesis, mendeskripsikan masalah, memecahkan masalah berdasarkan data dan masalah, kemampuan memahami kata dalam konteks, prioritas guru tetap pada bentuk soal penugasan dan uraian. Namun, perlu kecermatan dan ketepatan dalam pembuatan rubrik penilaiannya atau penskorannya. Mengingat soal jenis esai memiliki kekurangan antara lain lama dan cenderung subjektif dalam pemberian nilainya, maka jenis pilihan ganda dengan tetap menyertakan alasan tepat untuk digunakan untuk uji kompetensi membaca dan menulis. Pilihan ganda yang disertai respon tambahan dari peserta didik saat menyelesaikan masalah (soal) dapat digunakan oleh guru sebagai sarana refleksi dan menjadi informasi tentang kualitas respon peserta didik berdasarkan isi alasannya tersebut. Dengan demikian, guru dapat mengambil keputusan untuk menindaklanjuti.

Seperti yang terungkap dalam landasan teori bahwa taksonomi SOLO mengakomodasi tingkat berpikir peserta didik berdasarkan respon atas masalah (soal) yang dikerjakannya, tepatlah jika taksonomi ini digunakan dalam pengembangan perangkat evaluasi selain taksonomi hasil belajar yang selama ini digunakan dan bahkan telah direkomendasikan dalam standar penilaian (Biggs dan Collis 1982:12). Taksonomi SOLO sangat tepat digunakan dalam pengembangan perangkat evaluasi hasil belajar bahasa dan sastra Indonesia karena dapat digunakan untuk menentukan berada di level berpikir mana peserta didik. Dari hasil merespon jawaban dapat digolongkan peserta didik berada pada level mana apakah unistruktural, multistruktural, relasional, ataupun abstrak diperluas. Hal tersebut sejalan dengan penelitian yang dilaksanakan oleh Alsaadi (2001) dalam Jurnal Winter, J. (Ed.) Proceedings of the British Society for Research into Learning Mathematics 21 (3) November 2001, halaman 1-6 melakukan penelitian dengan judul "A Comparation of Primary Mathematics Curriculum England and Qatar: the Taxonomy SOLO". Alsaadi (2001) memaparkan harapan dari peserta didik di Inggis berusia 7 dan 11 tahun lebih pandai daripada peserta didik di Qatar. Simpulan dari penelitian tersebut tentang penggunaan taksonomi SOLO yang sangat cocok diterapkan pada anak usia 7-11 tahun karena dalam usia tersebut perkembangan otak anak akan terasah dengan cara dituntut untuk berpikir kognitif tingkat tinggi. Selain itu, Alsaadi juga membandingkan antara kurikulum Matematika dasar di Inggris dan Qatar sebagai bahan acuan dalam melakukan penelitian.

Hal senada dipaparkan Hong (2002) dalam Assessment $\mathcal{E}$ Evaluation in Higher Education, Vol. 27, No. 6, halaman 511-527 yang berjudul "Applying the Structure of the Observed Learning Outcomes (SOLO) Taxonomy on Student's Learning Outcomes: an empirical study". Hong (2002) menjelaskan penggunaan metode taksonomi SOLO dalam pembelajaran pendidikan menengah atas akan dapat menyelesaikan permasalahan yang terjadi. Hal ini menimbulkan anggapan bahwa model taksonomi SOLO menuntut agar peserta didik menyelesaikan masalah dengan berpikir tingkat tinggi terhadap respon permasalahan yang dihadapi, Hong (2002) tidak hanya menjelaskan tentang taksonomi SOLO saja tetapi juga menjelaskan taksonomi Bloom. Jurnal penelitian ini berisikan tentang apa saja yang termuat dalam taksonomi dan penerapan dalam pembelajaran. 
Penelitian serupa dilakukan Holmes (2004) dalam artikel A paper for presentation at the Australian Association for Educational Research Annual Conference, Melbourne yang berjudul "Analysis of a synchronous Online Discussion using the SOLO Taxonomy a paper for presentation at the Australian Association for Educational Research Annual Conference". Hasil penelitian Holmes (2004) adalah pembelajaran yang dilakukan secara online melalui internet dengan menggunakan analisis taksonomi SOLO yang dilakukan dalam penelitian pendidikan akan menhasilkan dampak yang baik pada pembelajaran Matematika. Pembelajaran ini melibatkan guru dan peserta didik yang saling berkomunikasi lewat online dikarenakan jarak antara guru dan peserta didik yang berjauhan maka dari itu diciptakan pembelajaran online, pembelajaran ini dibidang mata pelajaran matematika. Hasil penelitian yang dilakukan oleh Holmes (2004) adalah mendapatkan data berupa pengelompokan peserta didik yang sesuai penalaran taksonomi $S O L O$ yaitu tingkatan unistruktural (52\%), tingkatan multistruktural $(19,3 \%)$, tingkatan rasional $(30,1 \%)$, dan tingatan abstrak $(2,6 \%)$.

\section{Keterbatasan Penelitian}

Penelitian ini telah diusahakan agar sesuai dengan prosedur penelitian yang digunakan. Namun demikian, tidak dapat dimungkiri bahwa terdapat banyak kekurangan dan keterbatasan. Perlu diungkapkan di sini agar tidak terjadi kesesatan dalam penggunaan hasilnya. Keterbatasan yang dimaksud menyangkut beberapa aspek, yaitu 1) sumber data penelitian, 2) instrumen penelitian, 3) isi panduan, 4) latar pengisian angket kebutuhan, dan 5) penyusunan panduan. Uraian dari kelima aspek adalah sebagai berikut.

\section{SIMPULAN DAN SARAN}

Atas dasar hasil penelitian dan pembahasan yang dipaparkan, disimpulkan hal-hal berikut: (1) karakteristik perangkat evaluasi berdasarkan taksonomi SOLO kompetensi menulis dan membaca yang sesuai dengan kebutuhan guru dan peserta didik meliputi soal pilihan ganda, soal esai, soal menjodohkan, soal penugasan, kemampuan berpikir kritis, kemampuan memecahkan masalah; (2) prinsip-prinsip pengembangan perangkat evaluasi berdasarkan taksonomi SOLO kompetensi menulis dan membaca meliputi batasan pengembangan soal pilihan ganda, soal esai, soal menjodohkan, soal penugasan, jenis soal untuk kemampuan berpikir kritis, jenis soal untuk kemampuan memecahkan masalah; (3) produk pengembangan dalam penelitian ini berupa perangkat evaluasi berdasarkan taksonomi SOLO kompetensi menulis dan membaca. Isi perangkat evaluasi berdasarkan taksonomi SOLO kompetensi menulis dan membaca berupa konseptual materi, kisi-kisi evaluasi, kartu soal, paket soal lengkap dengan petunjuk pengerjaan, kunci jawaban dan rubrik penilaian dan peskoran; dan (4) perangkat evaluasi berdasarkan taksonomi SOLO kompetensi menulis dan membaca dilihat dari validitas, reabilitas, indeks tingkat kesukaran, dan daya pembeda soal.

Saran peneliti berkenaan dengan hasil penelitian pengembangan perangkat evaluasi berdasarkan taksonomi SOLO kompetensi menulis dan membaca antara lain: (1) perangkat evaluasi berdasarkan taksonomi SOLO kompetensi menulis dan membaca dibutuhkan guru untuk digunakan dalam pembelajaran. Oleh karena itu, perangkat evaluasi dpat dimanfaatkan untuk uji kompetensi menulis dan membaca. Selain itu, diharapkan pula dapat dimanfaatkan dalam pembelajaran membaca maupun menulis baik aspek kesastraan maupun nonsastra; (2) perangkat evaluasi berdasarkan taksonomi SOLO 
ini masih mungkin untuk dikembangkan lebih lanjut seiring dengan berkembangnya kebutuhan guru, kebutuhan zaman, dan berkembangnya ilmu pengetahuan dan teknologi bidang pendidikan.

\section{UCAPAN TERIMA KASIH}

Peneliti ini mengucapkan terima kasih kepada Direktur Pembinaan Penelitian dan Pengabdian pada Masyarakat (P3M) Ditjen Dikti, Kemendikbud, atas kepercayaan yang diberikan untuk melaksanakan proyek penelitian ini. Ucapan terima kasih disampaikan juga kepada Ketua Lembaga Penelitian dan Pengabdian pada Masyarakat (LP2M) UNNES, yang telah berkenan memberikan fasilitas kemudahan dalam hal pengurusan izin penelitian serta memberikan pengarahan untuk penyelesaian penelitian ini.

Penghargaan khusus, sekalipun hanya berupa kata-kata, tim peneliti ini tujukan kepada subjek penelitian yang telah meluangkan waktu untuk diajak berdialog saat pengumpulan data. Penghargaan tersebut juga tim peneliti ini sampaikan kepada rekan-rekan sekantor yang telah berkenan sebagai teman berdiskusi berkenaan dengan masalah pengembangan perangkat evaluasi.

\section{DAFTAR PUSTAKA}

Alsaadi, Aziza. 2001. "A Comparison of Primary Mathematics Curriculum England and Qatar: The SOLO Taxonomy." University of Surrey Roehampton: available.

Bigg, J. B. dan Collis. 1982. Evaluating The Quality of Learning: The Solo Taxonomy. New York: Akademik Press Inc.

Bloom, Benyamin S. 1979. Taksonomy of Educational Objectives (The Clasification of Educational Goals) Handbook 1 Cognitive Domain. London: Longman Group Ltd.
Dahmani. 2012. "Automatic Evaluation Learners with Odala: Application to Releation Database E-Learning". International Journal of Computational System. Vol 03 no. 03. Hal 357-365.

Dharma, Surya. 2009. Profil dan Masa Depan Pendidikan. Jakarta: Balitbang Depdiknas.

Djiwardono, M. Soenardi. 2008. Tes Bahasa Pegangan bagi Pengajar Bahasa. Malang: Universitas Negeri Malang.

Borg, Walter R., Gall, Meredith D., dan Joyce P. Gall. 1983. Educational Research An Introduction. New York: Pearson Education, Inc.

Hamalik, Oemar. 2008. Perencanaan Pengajaran Berdasarkan Pendekatan Sistem. Jakarta: Bumi Aksara.

Holmes, Kathryn. 2004. "Analysis of Asynchronous Online Discussion using the SOLO Taxonomy A paper for presentation at the Australian Association for Educational Research Annual Conference." Melbourne: University of Newcastle. Educational and Development Journal : Nov-Dec 2004.

Kayanni, Muhammad Abid Husain, Muhammad Ajmal, Fazalur Rahman. 2010. “Teacher's Perseption Regarding Examination Based SOLO Taxonomy" International Journal of Academic Research. Vol. 2, No. 6, November 2010, Hal 208-211.

Hong, Joe et al. 2002. "Applying the Structure of the Observed Learning Outcomes (SOLO) Taxonomy on Student's Learning Outcomes: an empirical study. Hongkong: University of Hongkong." Journal International: Assessment $\mathcal{E}$ Evaluation in Higher Education, Vol. 27, No. 6.

Kenny, John. 2002. SOLO Taxonomy. New York: RMIT University. 